\title{
Secularization and Sacralization. New polarization of the Polish religious landscape in the context of globalization and European integration
}

\author{
ELŻBIETA BILSKA-WODECKA \\ Jagiellonian University, \\ Institute of Geography and Spatial Management
}

\begin{abstract}
The fall of the Communist government gave rise not only to changes in the political, economic, and social realm of Poland but also came to exert an impact on the country's religious character. Statistical data, especially that collected over the last five years, indicate changes in the religious character of Polish society. This is manifested in a decreasing number of individuals attending Sunday Mass and an increasing number of individuals receiving Holy Communion. Other developments noted in recent years include changes in the number of baptisms and seminarians studying to become priests.

The opening of national borders and new limits on government control over Roman Catholic Church activity as well as the actions of other denominations created an atmosphere conducive to a reconnection with like-minded individuals abroad. International religious meetings became an option with foreign religious denominations now faced with an opportunity to perform missionary work in Poland.

Poland's decision to pursue membership in the European Union (EU) stirred up a heated social debate. The Roman Catholic Church was in favor of joining the EU, however, some individuals in both institutional and lay circles had some reservations regarding that decision.
\end{abstract}

Key words: Poland - Roman Catholic Church - secularization - EU membership

\section{Introduction}

Poland was one of the few countries in the so-called Eastern Bloc (1945-1989) where most churches and denominations, while under government surveillance, were able to function to some extent. In Poland, their ability to function was limited by the National Security Agency (Polish acronym: SB) as well as a special agency called the Office of Faith Affairs. Poland's denominational structure changed radically following the border changes, deportations, and repatriations associated with the post-1945 era. Today, it is difficult to speak of religious pluralism in Poland, with the country being 90\% Roman Catholic for the last 60 years. The Roman Catholic Church clearly dominates the religious landscape of Poland today.

Today, Polish society remains in a transition state between a monocentric social model of the pre-1989 Communist era and a post-monocentric social model of the 
modern Capitalist era, with a polycentric social model within sight. Modern Polish society is described as a traditional-to-postmodern "transition society" based on the characteristics it represents (Mariański 1998). Many areas of life in Poland are experiencing abrupt changes, which are not neutral with respect to the shaping of social attitudes towards religion, the institutional Church, and consequently, the religious nature of each individual.

The aim of the article is to present changes taking place in the religious lives of members of the Roman Catholic Church following the fall of the Communist system in Central and Eastern Europe, taking into account the role of globalization as well as integration with the European Union.

\section{Secularization, sacralization, and polarization of faith in Polish society}

The systematic and often quite brutal policies of Communist governments towards churches and other denominations led to a significant decline in the number of faithful in many countries. When the Communist system collapsed in Central and Eastern Europe in 1989, large numbers of non-religious individuals had already become a permanent fixture in most so-called post-Communist countries.

The religion situation in Poland is different from that in other postCommunist countries. According to official statistical data, the number of individuals belonging to religious minorities has remained steady for the last few decades. On the other hand, the number of Roman Catholic faithful started to decline in the mid-1990s. At the same time, the number of non-religious individuals and those not connected with any religious group rose from $2.6 \%$ in 1990 to $8.0 \%$ in 2005 (Table 1). The statistical information available on the number of individuals belonging to churches and other denominations is based on an imperfect data collection system. The data may be best viewed as estimates. The Main Statistical Office (Polish acronym: GUS) obtains data from surveys mailed to religious institutions and not from Census forms that are filled out by private individuals.

The Catholic Church was a very important social institution during the Communist era in Poland. Its role and significance were summarized in a domesticallyproduced report issued abroad in 1986: "The Church's moral teaching is an important countermeasure against social and psychological threats (...). The moral and social authority of both the Pope and the clergy remains high. In a sense, and perhaps paradoxically, this is beneficial to the national government.

The different community-building aspects of the Church as well as the rich and well-developed pastoral programs designed for farmers, students, creative minds, and even workers constitute an immensely effective force of social integration, personal development, and moral awareness. While the Church is an integral part of Polish society and a voice of Poland, it is also a very important mediator in the realm of social issues and politics" (Raport ... 1986). 
Tab. 1 The denominational profile of Poland (1990, 1995, 2000, 2005, 2007)

\begin{tabular}{|c|c|c|c|c|c|c|c|c|}
\hline \multirow{2}{*}{ Year } & \multicolumn{2}{|c|}{ Total population } & \multicolumn{2}{c|}{ Roman Catholic Church } & \multicolumn{2}{c|}{ Other religions } & \multicolumn{2}{c|}{ No religion } \\
\cline { 2 - 9 } & {$[\mathbf{1}]$} & {$[\mathbf{2}]$} & {$[\mathbf{1}]$} & {$[\mathbf{2}]$} & {$[\mathbf{1}]$} & {$[\mathbf{2}]$} & {$[\mathbf{1}]$} & {$[\mathbf{2}]$} \\
\hline 1990 & $38,119,000$ & 100.0 & $35,894,538$ & 94.2 & $1,227,893$ & 3.2 & 996,569 & 2.6 \\
\hline 1995 & $38,609,399$ & 100.0 & $34,908,739$ & 90.4 & $1,005,507$ & 2.6 & $2,695,153$ & 7.0 \\
\hline 2000 & $38,646,000$ & 100.0 & $34,608,967$ & 89.5 & 995,450 & 2.6 & $3,041,583$ & 7.9 \\
\hline 2005 & $38,157,010$ & 100.0 & $34,197,400$ & 89.6 & 901,559 & 2.4 & $3,058,051$ & 8.0 \\
\hline 2007 & $38,116,600$ & 100.0 & $33,699,264$ & 88.4 & 986,059 & 2.6 & $3,431,277$ & 9.0 \\
\hline
\end{tabular}

Notes: [1] Number of persons; [2] Percent of total population.

Source: compilation of data based on: Rocznik Statystyczny Rzeczypospolitej Polskiej 1991, 1991: 57-58; Rocznik Statystyczny Rzeczypospolitej Polskiej 1996, 1996: 72-74; Rocznik Statystyczny Rzeczypospolitej Polskiej 2001, 2001: 120-121; Rocznik Statystyczny Rzeczypospolitej Polskiej 2006, 2006: 220-221; Rocznik Statystyczny Rzeczypospolitej Polskiej 2008, 2008: 212-213.

In 1989, the Church came face to face with a new situation. The Communist system had fallen and Polish society began to revise its views on the meaning of religion in the life of the individual. Changes in religious attitudes in Poland are taking place on several levels. This begs the question: Where are these changes in religious attitude headed in Poland? According to I. Borowik (1997: 10), the various factors that can be thought of as being empirical evidence of progressive laicization only affected Polish society to some extent. These factors include the separation of Church and state in 1945, the secularization of many national institutions such as public schools, declining attendance at Sunday Mass (Table 3), decreasing numbers of Church-approved marriages and funerals, and smaller numbers of candidates at seminaries and religious orders (Table 4) up to the late 1990s.

J. Mariański (2004), on the other hand, believes that there are two schools of thought among sociologists who study religious issues in the post-1989 world. One group of sociologists believes that "the transition from totalitarianism to democracy has not been relevant in the realm of religion" (Piwowarski, Podgórska 1999: 456). The other group believes that the calling of religious beliefs into question and the adoption of a lay lifestyle is a consequence of social modernization modeled by the countries of Western Europe. The ongoing transition may result in a smaller number of individuals engaging in religious practices.

Mariański (2004) believes that given a lack of accurate data on the denominational structure of the country, baptismal records may be an important source of information on the number of individuals associated with different denominations in Poland. In Poland, baptism is a mass phenomenon. Being baptized is a "cultural must" and few individuals decline to baptize their children. In recent years, the number of baptized children with parents who have only had a civil marriage ceremony is rising. The period of time between birth and baptism is also becoming longer. Finally, some non-Catholic families are now choosing to baptize their children (Mariański 2004).

Between 1970 and 2007, over 92\% of individuals in Poland were baptized by the Roman Catholic Church (Table 2). During the first half of the 1980s, the rate of 
baptism exceeded $100 \%$ given the large number of adults wishing to be baptized. The Communist government had an unspoken policy of letting go of military, police, management, and government employees who baptized their children. This policy was abandoned to some extent following the year of martial law in 1981. Many individuals who had been afraid to openly participate in religious practices before were now more free to become baptized.

Tab. 2 Live births and baptisms in the Catholic Church in Poland from 1970 to 2007

\begin{tabular}{|l|c|c|c|}
\hline Year & Live births & Baptisms in the Catholic Church $^{\mathbf{a}}$ & Baptisms as a percentage of live births \\
\hline 1970 & 545,973 & 516,984 & 94.69 \\
\hline 1975 & 643,772 & 596,326 & 92.63 \\
\hline 1980 & 692,798 & 685,037 & 98.88 \\
\hline 1981 & 678,696 & 711,351 & 104.81 \\
\hline 1982 & 702,351 & 727,058 & 103.52 \\
\hline 1983 & 720,756 & 747,646 & 103.73 \\
\hline 1984 & 699,041 & 741,766 & 106.11 \\
\hline 1985 & 677,576 & 637,606 & 94.10 \\
\hline 1990 & 545,817 & 569,154 & 104.28 \\
\hline 2000 & 378,348 & 379,088 & 100.20 \\
\hline 2001 & 368,205 & 367,425 & 99.79 \\
\hline 2002 & 353,765 & 353,975 & 100.06 \\
\hline 2003 & 351,072 & 343,711 & 97.90 \\
\hline 2004 & 356,131 & 342,413 & 96.15 \\
\hline 2005 & 364,383 & 351,368 & 96.43 \\
\hline 2006 & 374,244 & 353,263 & 94.39 \\
\hline 2007 & 387,873 & 366,610 & 94.52 \\
\hline
\end{tabular}

Note: ${ }^{a}$ The number of baptisms is the total number of baptisms of children under the age of 7 and adults. Source: compilation of data based on: GUS Regional Data Bank (Bank Danych Regionalnych GUS) 2009; Mariański 1993: 59; Adamczuk, Zdaniewicz, Zieba (eds.) 2006: 63.

In this paper, changes in Catholic religious attitudes are quantified using a percentage index of individuals participating in Sunday Mass (dominicantes) and individuals receiving Holy Communion (communicantes). A decrease in the number of individuals participating in Sunday practices may produce negative effects in the realm of religious beliefs (Mariański 2004). In Poland, the high level of participation in religious practices is associated with trust in the Catholic Church. Religion is viewed as being a way of life. A general decrease in the dominicantes index $(-10.6 \%)$ can be observed for the 1980-2008 time period for Poland as a whole (Table 3).

In the last twenty years, religious behavior in Poland has followed a cyclical pattern with increases being noted following key historical events such as the imposition of martial law and the creation of the first non-Communist Polish government in 1989. The latter event brought about a spike in religious behavior, which then proceeded to gradually decline. According to W. Piwowarski, religious behavior on a national scale will continue to decline in concert with weakening political and pa- 
triotic factors, which have traditionally served to maintain and prompt religious behaviors (Mariański 2000). The values that the Catholic Church teaches are no longer recognized as important by a large fraction of Polish society, which is slowly drifting away from traditional values towards "modern" values (Mariański 2000). This trend is especially clear with young people who tend to abandon Sunday religious practices.

Tab. 3 Percentage of dominicantes and communicantes in Poland between 1980 and 2008 following selected political events

\begin{tabular}{|l|c|c|}
\hline Year & Percentage of dominicantes & Percentage of communicantes \\
\hline 1980 & 51.0 & 7.8 \\
\hline 1981 & 52.7 & 8.1 \\
\hline $1981-$ martial law \\
\hline 1982 & 57.0 & 9.6 \\
\hline 1985 & 49.9 & 9.1 \\
\hline 1988 & 48.7 & 10.7 \\
\hline 1989 & 46.7 & 9.9 \\
\hline $1989-$ start of transition to democracy \\
\hline 1990 & 50.3 & 10.7 \\
\hline 1995 & 46.8 & 15.4 \\
\hline 2000 & 47.5 & 19.4 \\
\hline 2001 & 46.8 & 16.5 \\
\hline 2002 & 45.2 & 17.3 \\
\hline 2003 & 46.0 & 16.9 \\
\hline 2004 & 43.2 & 15.6 \\
\hline 2005 & 45.0 & 16.5 \\
\hline 2006 & 45.8 & 16.3 \\
\hline 2007 & 44.2 & 17.6 \\
\hline 2008 & 40.4 & 15.3 \\
\hline
\end{tabular}

Source: selected data from Zdaniewicz, Adamczuk 2009.

As the role and significance of traditional religious, social, cultural, as well as political motivations wane, general religious attitudes based on such motivations will also start to change. The increase in religious behaviors in Poland in the 1980s was first and foremost a manifestation of non-religious (nationalist) values. The Catholic Church was able to strengthen its social and moral authority thanks to its association with political movements (so-called political religion) (Mariański 1993).

In Poland, it is possible to identify several regions that are quite distinct in terms of the extent of religious practices. The following dioceses are considered to be the most religious in Poland: Tarnów, Przemyśl, and Rzeszów (Figure 1). Their dominicantes index ranges from $59.0-87.0 \%$. The dioceses considered to be the least religious are those located in western and northern Poland - areas annexed by Poland after World War II - with the dominicantes index ranging from $26.8 \%$ to $55.1 \%$. This includes the Szczecin-Kamień Diocese, the Koszalin-Kołobrzeg Diocese, and 
the Elblag Diocese. Other dioceses that are viewed as not very religious are Łódź (25.6-39.2\%) and Sosnowiec (27.9-35.8\%).

While the percentage of individuals attending Sunday Mass in Poland (dominicantes) continues to decline, the number of individuals receiving Holy Communion (communicantes) continues to increase. Nationally, the communicantes index increased $7.5 \%$ between 1980 and 2008. This suggests a change in the quality of faith in Poland. More Catholics are trying to live according to the principles of their faith. The highest values of the communicantes index have been recorded in the following dioceses: Opole (10.5-25.6\%), Katowice (9.7-20.1\%), Tarnów (9.0-27.5\%), and Poznań (9.6-23.0\%). The lowest values have been recorded in these dioceses: Łódź (5.4-12.5\%), Włocławek (5.7\%-13.2\%), Szczecin-Kamień (6.7-12.8), and Sosnowiec (8.9-1.6\%).

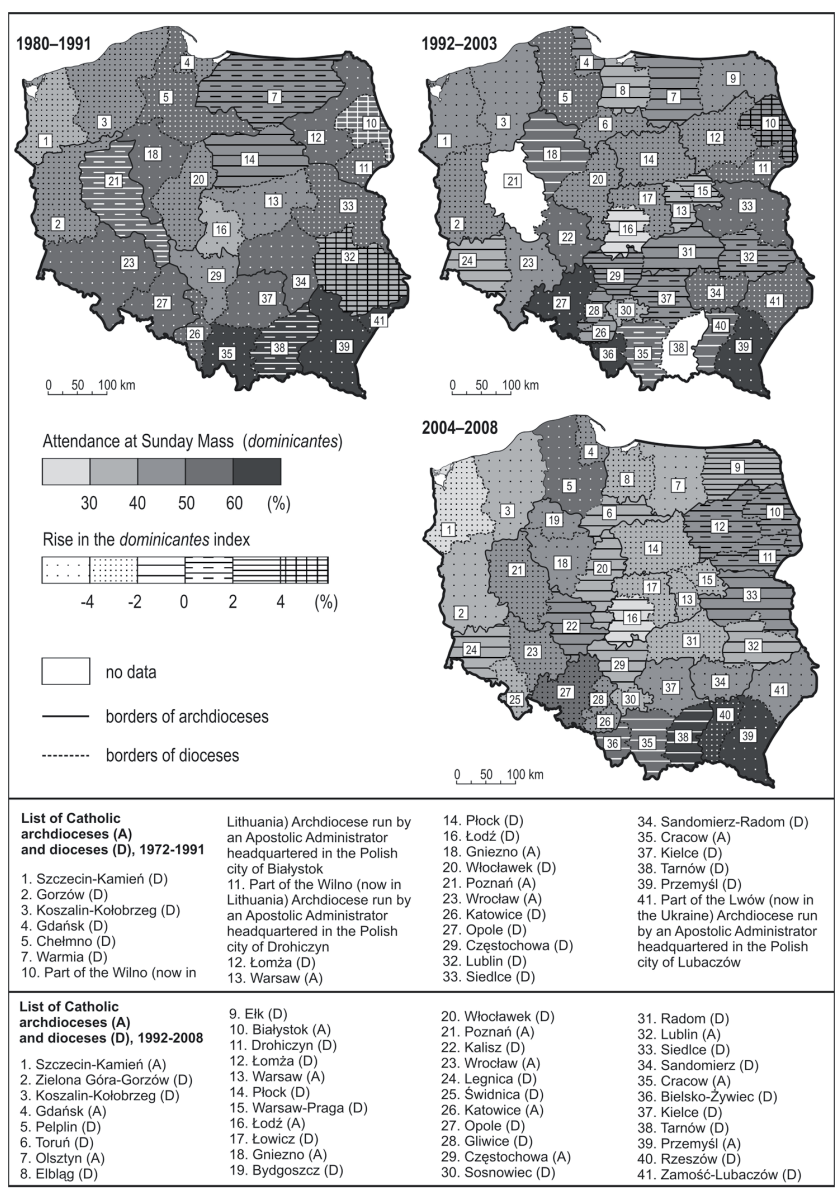

Fig 1 The dominicantes index for 1980, 1992, and 2004 as well as increases in the index for 1980-1991, 1992-2003, and 2004-2008

Source: prepared by author, based on data from Zdaniewicz, Adamczuk 2009. 
Another important measure of the religious attitudes of a society is the number of individuals deciding to join a seminary. Statistical data obtained from diocesan seminaries and convents for the 1971-2008 time period indicate a substantial rise in the number of vocations to the priesthood from 1980 to 1990 both on a diocesan scale and a national scale. The reasons for this may be both religious and nonreligious in nature. It is important to keep in mind the unique environment created by the pontificate of John Paul II as well as the political, social, and economic changes taking place in Poland at the time. Survey research conducted at seminaries has shown that of the motives compelling men to enter the priesthood, $37 \%$ of the candidates surveyed indicated that the election and pontificate of John Paul II had a meaningful impact on their choice of "career" (Adamczuk, Zdaniewicz 1991).

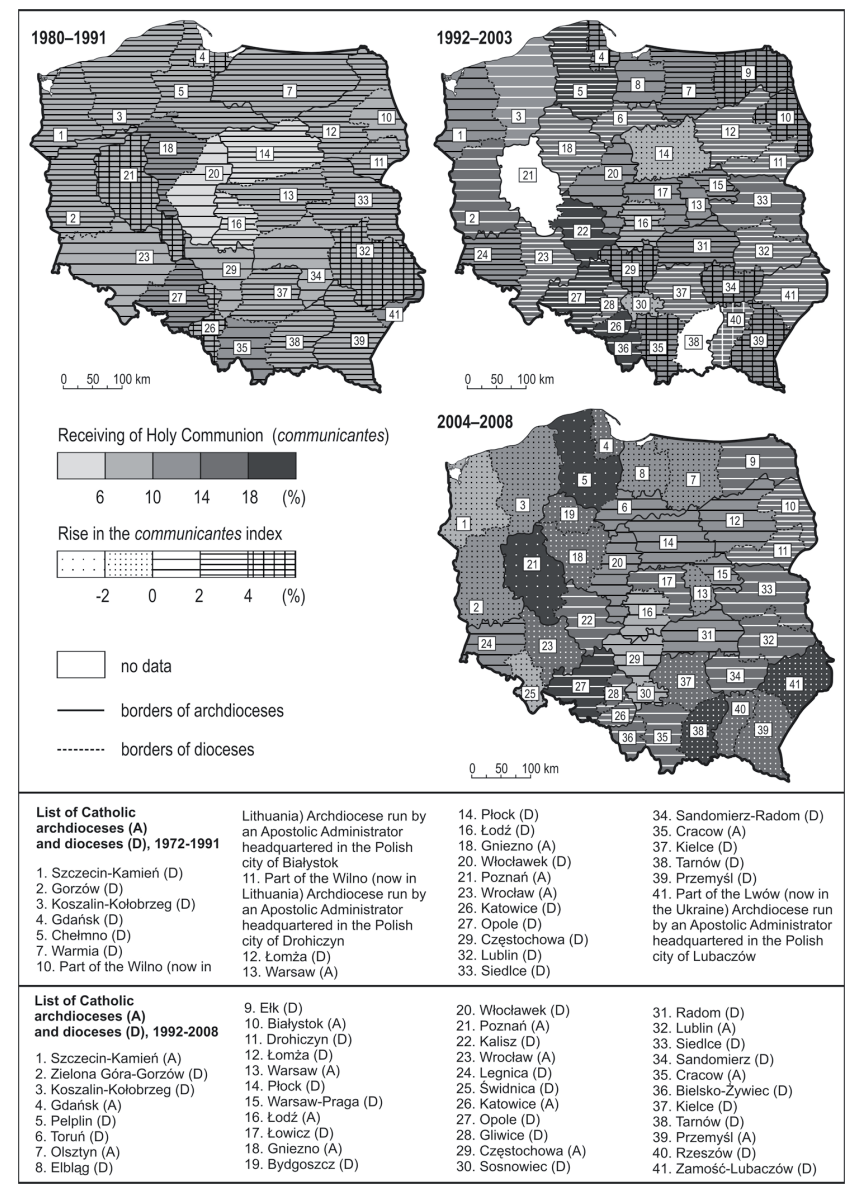

Fig 2 The communicantes index for 1980, 1992, and 2004 as well as increases in the index for 1980-1991, 1992-2003, and 2004-2008

Source: prepared by author, based on data from Zdaniewicz, Adamczuk 2009. 
The number of seminarians and individuals entering convents began to decline in 2005. A number of reasons have been cited for this including a demographic low taking a hold of Poland, young people moving abroad in search of work, and an increasing reluctance on the part of parents to accepts a child's decision to enter a seminary or convent. Another reason for the decline may be a negative image of the Catholic Church being transmitted via the mass media (Wojas 2009).

Tab. 4 Number of seminarians and religious order candidates between 1971 and 2008

\begin{tabular}{|c|c|}
\hline Year & $\begin{array}{c}\text { Number of seminarians and } \\
\text { religious order candidates }\end{array}$ \\
\hline 1971 & 4,088 \\
\hline 1975 & 4,395 \\
\hline 1980 & 6,285 \\
\hline 1985 & 8,464 \\
\hline 1990 & 8,554 \\
\hline 2000 & 6,712 \\
\hline 2005 & 6,204 \\
\hline 2008 & 5,583 \\
\hline
\end{tabular}

Source: Compilation of data based on: Adamczuk, Zdaniewicz 2000-2007; Statystyka Kościoła katolickiego 2005; Łoziński 2007; Wojtas 2009.

Research conducted by the the Institute of Catholic Church Statistics (Polish acronym: ISKK SAC) and the Denominational Research Team of the National Statistical Office (Polish acronym: GUS) produced the following data on the religious attitudes of Poles for the 1991-1998 time period (Zdaniewicz 2001: 8):

- the vast majority of Poles believe in God and faith is very important in their lives;

- faith in para-religious practices is not important to most Poles;

- the number of individuals who accept moral behaviors inconsistent with those taught by the Catholic Church is growing;

- a high percentage of Catholics still takes part in Sunday practices.

These conclusions remain valid in current research on religious behavior conducted by a number of different institutions such as the "Opinia" Center for Social Survey Research, the CBOS Public Opinion Research Center, and the Institute of Catholic Church Statistics.

A CBOS research study conducted in 2005 confirmed the hypothesis formulated by Zdaniewicz in 2001. Most members of Polish society declare an affiliation with the Roman Catholic Church. Most credit Pope John Paul II for having a significant influence on their religious views. The vast majority of Poles consider themselves to be people of faith (96\%), with $60 \%$ attending Mass at least once a week. Only $7 \%$ of individuals surveyed state that they do not take part in any religious practices. Most Poles consider the Ten Commandments to be the main set of principles shaping their lives. Only 3\% of individuals in Poland state that they do not attempt to follow the Ten Commandments on a daily basis (Wiśniewska 2005). 
A happy family is considered to be a top priority for $84 \%$ of individuals surveyed. Success and fame ranked somewhat lower. Who or what is responsible for the creation of this type of value system? Over $80 \%$ of surveyed individuals believe that John Paul II has had the greatest influence on their value system. Poles perceive his teaching to be almost as important as their own thoughts. Friends $(26 \%)$ and the media (20\%) are said to have less of an influence on the shaping of public opinion. The religious value statements that Poles make are not consistent with the their everyday behaviors, which often depart from the teachings of the Roman Catholic Church. Situational ethics often supersede absolutist Christian ethics.

Survey participants believe that either individuals or society should judge what is right and wrong. Over half of individuals surveyed (53\%) state that there are no absolute principles defining what is right and what is wrong, as everything depends on the circumstances. Only $27 \%$ of individuals surveyed, especially older individuals, claim that Divine Law provides the right set of principles to make such decisions. Differences between Roman Catholic doctrine and its application in everyday life can be observed in Polish society's liberal approach to sexual ethics. Premarital sex is considered to be immoral by only $32 \%$ of the surveyed population, while $28 \%$ condemns the use of artificial contraception.

The process of diversification and privatization of religion has been taking root in Polish society over the last 19 years. Some are becoming deeper believers while others are abandoning the faith. An increasing number of individuals are no longer afraid to declare themselves to be non-believers or followers of non-Catholic belief systems. This is especially true of those who claim non-believer status. The largest community of believers in Poland - the Roman Catholic Church - is witnessing the development of two basic trends: 1. a general religious trend, and 2. a Catholicnational trend, which aims to maintain the "Messianic tradition of the Polish nation".

This divergence in views was particularly vivid during the national debate on Poland's entry into the European Union. Changes in the public perception of the moral authority of the Church may be a symptom of the gradual secularization of Polish society. There is a growing number of areas of life where Poles claim they act more in accord with their own conscience than based on the teachings of the Catholic Church. On the other hand, one symptom of the growing sacralization of Polish society is the increase in the number of individuals regularly receiving Holy Communion (communicantes).

\section{The impact of globalization on the Polish religious landscape}

The fall of the Communist system in Poland created the opportunity for the development of religious pluralism. Along with the process of globalization and the opening of Poland's borders, the number of denominations in the country has 
grown. While this is not a far reaching phenomenon, it is worth mentioning. Poland has become a magnet for missionaries from religious communities in India, the Far East, as well as Protestant communities in other European countries and the United States (e.g. Mormons). The fall of Communism also made it possible for existing religious communities (e.g. Jehovah's Witnesses, Pentecostals) to contact likeminded individuals abroad. Finally, non-believers have become more willing to express their individual points of view.

Many communities are afraid of the unifying pressure being exerted by global culture. This is especially true of traditionalist and fundamentalist religious communities, which become energized by the pressure of globalization to fulfill one of their central roles in society - that of expressing and strengthening one's level of identification with a particular group. New forms of "religious nationalism" have emerged and religion has become a political tool and a means of pursuing national interests as well as a banner of loyalty to one's own group in the midst of conflict. Religion is also being used to prompt resentment of others. Such tendencies were on display in Catholic-nationalist circles, especially during the process of Poland's integration with the European Union.

The fear among many communities, evoked by the unification pressure of a global culture, provides religion - and particularly its traditionalist and fundamentalist forms - with energy to perform one of its social roles: to express and strengthen the sense of identification with the group. New forms of the "religious nationalism" are appearing - in several parts of the world, religion has become a tool for political and national interests, a flag that among conflicts should strengthen the sense of faithfulness towards one's own group and antagonism towards the others. Such tendencies could be observed among the national Catholic circles, particularly in the context of Poland's integration with the European Union.

\section{The Catholic Church and Poland's entry into the European Union}

Starting in 1989, when Poland became a free state once again, the Catholic Church in Poland decided to support the invariably pro-European policies of the Polish government. However, being a pastoral institution, the Church had to take into account the views of Polish society, especially that part of society for which European integration was an abstract and incomprehensible process.

A key event that helped to alleviate the fears of the faithful was a visit by Polish Cardinal Józef Glemp and a number of bishops to Brussels in November, 1997. Poland's top clergy had the opportunity to become familiar with the work of the European Commission, and shortly thereafter, came to wholeheartedly support Poland's integration with the European Union. Another outcome of the visit was the decision by Archbishop Henryk Muszyński to participate as an observer in the work of the Commission of Bishops' Conferences of the European Union (COMECE). 
Yet another visit in Brussels by Cardinal Józef Glemp in November of 2001 produced far reaching consequences. The Cardinal met with the EU Commissioner for Enlargement, Günter Verheugen. Following that meeting, the Cardinal declared that Poland's integration with the European Union is a "historical necessity" (Wiadomości KAI 2001). The conversation at the time focused on the role that the Catholic Church in Poland could play in the shaping of a pro-European orientation among its faithful. Several days later, Cardinal Glemp was interviewed by the Catholic Information Agency (Polish acronym: KAI). In the interview, he stated that while Poland may lose its national currency, the złoty, if its joins the European Union in favor of an EU currency, it will not lose its national or religious identity, as it possesses one of the strongest forms of national and religious identity in Europe. He also sought to assure Poles that the Polish Episcopate will not be divided on the issue of EU membership (Wiadomości KAI 2002c).

Polish bishops held a meeting in Częstochowa at the end of November, 2001, where they decided to first issue a brief communiqué and then a special pastoral letter dedicated to the issue of integration with the European Union. The communiqué was issued on March 21, 2002. Polish bishops voiced their support for integration with the European Union, treating it as an opportunity that Poland should take advantage of. The bishops also formulated a number of conditions that the new united Europe should fulfill.

They clearly stated that "[Poland's] inclusion in the European system ought not mean the abandonment of national, political, and cultural sovereignty as well as religious sovereignty" (Wiadomości KAI 2002a). The Episcopate also supported the idea that the proposed European Constitution include a reference to God in the form of an "invocatio Dei" (Wiadomości KAI 2002b).

The Catholic Church in Poland, as the cited communiqué suggests, expected European Union law to guarantee that human life would be protected from conception to natural death. A similar expectation applied to marriage, defined as a union between a man and a woman. The Church also assumed that EU law would provide churches and other denominations with a clear legal status and not just a generally defined notion of freedom of conscience and belief or freedom from discrimination.

The decision to publish official statements by the Conference of the Episcopate on the issue of European integration was a sign that Poland's top clergy were worried by the anti-EU campaign being actively waged by some Catholic circles (e.g. Radio Maryja - Catholic radio station founded by the Redemptorist Fathers in Toruń in 1991 and other Catholic-nationalist interest groups - "Niedziela" weekly, "Nasz Dziennik" weekly, League of Polish families), which were undaunted by the pro-EU position held by the Conference of the Episcopate.

The notion that Poles should not only be responsible for their own religious identity but for the religious identity of a unified Europe was advanced by John Paul II in his teaching efforts during his pilgrimages to Poland. The Pope not only underscored the importance of the European unification process but also chal- 
lenged Poles to provide the new Europe with a Christian example. In his message to the Conference of the Episcopate in 1997, he wrote: "the Church in Poland can offer a unifying Europe the example of its commitment to faith, its religious lifestyle, the pastoral commitment of its bishops and priests, as well as many other values that could help the new Europe become a deeply spiritual organism and not just an economically advanced entity" (John Paul II 1998: 24).

In 1999, John Paul II reminded his hesitant countrymen that "the integration of Poland with the European Union has been supported by the Holy See from the very beginning" (John Paul II 1999: 103). The issue of Poland's integration with a united Europe was once again on the Holy Father's agenda when he came to visit Poland for the last time in 2002. Prior to departing Balice airport, he once again voiced his support for integration with the following words: "I do hope that Polish society will continue to nurture the values that make it European and will find its place in the realm of the European Community, and not only not lose its own identity, but enrich the continent and the world with its traditions" (John Paul II 2002: 135).

The EU membership referendum in Poland was undoubtedly affected by the statement issued by John Paul II on May 19, 2003, where he voiced his support for membership in the European Union: "Today, when Poland and other countries of the former Eastern Bloc are about to enter the European Union, I repeat these words to you. I am not saying them to discourage you. Actually, the opposite is true. I wish to let you know that these countries have an important mission to complete in the Old Continent. I know that there are many opponents of integration. I value their concern for the cultural and religious identity of our Nation."

I share their fears associated with the division of economic power. Poland has been the victim of a fraudulent economy run by the former system, and while it appears to be a land of great opportunity, it is also a land of meager means. However, I wish to underscore the fact that Poland has always been an important part of Europe, and today, it cannot exclude itself from this community, which may be suffering a number of different crises, but which constitutes one family of nations rooted in a common Christian tradition. Poland's entry into the European Union, based on equal rights with other countries, is a type of manifestation of poetic justice for our Nation and for our brotherly Slavic nations that may also be a means of enriching all of Europe. Europe needs Poland. The Church in Europe needs the Christian example of Poles. Poland needs Europe (John Paul II, 2003).

The opinion of John Paul II was important to Catholic-nationalist circles associated with Radio Maryja, the "Niedziela" weekly, the "Nasz Dziennik" daily, and the League of Polish Families. It had the effect of weakening their anti-EU stance. The biggest surprise came in the form of less anti-EU rhetoric from Radio Maryja. On Thursday (May 22, 2003), Radio Maryja director Fr. Rydzyk stated on the air that "when the Holy Father says something, we do not argue with the Holy Father and do not comment on his statements. We wish to spread his teachings. (...) I would like to ask Radio Maryja listeners who call in to not campaign for one side or the other. (...)." 
Shortly thereafter, however, during a Radio "Nasz Dziennik" Weekend, Fr. Rydzyk read a speech made by Archbishop Kazimierz Majdański (dated May 9, 2003) at the Family Research Institute of the Cardinal Stefan Wyszyński University in Warsaw, where the Archbishop asked: "Who closed our door to Europe and who wants to open it for us at an exorbitant price?" And he replied: "The price is not only our sovereignty and our land but also our faith in God and our faith in His commandments (...)."

The League of Polish Families did not abandon its campaign against Poland's entry into the European Union, although it did acknowledge that the Pope supports Poland's membership. Roman Giertych commented on the part of the speech where the Pope speaks of so-called Euro-skeptics. Member of Parliament Bogdan Pęk, who had often spoken on the air on Radio Maryja as an expert in European issues, explained the problem this way: "The Holy Father certainly must not have become familiar with the Membership Treaty and all of the conditions that apply to Poland. If he were more familiar with the conditions of Poland's entry into the EU, then he would not speak of it in the manner that he has. (...) President Kwaśniewski must have talked the Pope into supporting Poland's integration with the EU so openly." Pęk's comments were strongly criticized by the Minister for European Affairs, Danuta Hübner: "I think that the Holy Father is fully aware of the details of the EU Membership Treaty and the Vatican has a keen understanding of the consequences of EU enlargement. To claim otherwise is going too far."

The speech by John Paul II also did not change the anti-EU stance of the Self Defense Party, which restated its views at a general meeting of its members on May 24, 2003 in Warsaw. The leader of Self Defense, Andrzej Lepper, stated in an interview with the "Gazeta Wyborcza" national daily: "I never said that we are against integration because it threatens the Catholic faith or our national identity. We are not LPR (Polish acronym for League of Polish Families) and we do not scare people with this sort of stuff. I am simply saying that the negotiated membership terms are unfavorable. (...) However, we have no intention of talking anyone into voting "no". Our motto is: 'The choice is yours'. The Holy Father supports Poland's entry into the European Union, however, he has given consideration to economic issues. I, on the other hand, have to watch over the interests of the voters." A Member of Parliament from the Self Defense party, Danuta Hojarska, issued an even stronger statement in the "Dziennik Bałtycki" daily: "If the Pope wants Polish farmers to perish, then I will defend them."

The clarity of the Pope's words surprised even Polish bishops. Archbishop Tadeusz Gocłowski told the "Rzeczpospolita" daily: "Personally, I expected an unambiguous response from the Holy Father, however, he surprised us a little with the clarity of his formulation. (...) In its most recent letter, the Episcopate issued an unambiguous assessment of the Pope's past statements on the issue of integration, however, the Pope went one step further in terms of the clarity of his stance on the issue that the nation must decide on when it votes on June $7^{\text {th }}$ and $8^{\text {th }}$. The Pope's emphasis was even stronger." 
Archbishop Damian Zimoń, who had already in December voiced his support for Polish membership in the EU, also noticed differences between the Pope's statements made in Saint Peter's Square and the Polish bishops' letter published before the referendum on Poland's EU membership. The Bishop of Katowice stated: "While the Polish Episcopate has spoken on the issue of integration in its most recent letter, it does seem appropriate to state even more clearly that Poland needs to be part of a united Europe - it needs to take its rightful place in the EU and "do its job". He went on to say: "We need to speak as one with the Holy Father, so that the faithful will understand where we stand. It is difficult to force anyone to do anything or to impose anything on anyone - we do not want that - but our views on the issue are clear."

The impact of the statements of John Paul II became apparent when prereferendum public opinion surveys results were compared with the actual results of the referendum. At least some of the inhabitants of eastern and southern Poland who had opposed EU membership before, came to support the idea on the day of the referendum. The referendum also shed light on the fact that Poles did not trust top Church officials all that much, while most did consider Pope John Paul II to be an unquestionable source of authority.

In order for the referendum to be legally binding, more than $50 \%$ of eligible voters had to take part in it. Top Church officials made an appeal to the public to perform its civic duty. They rationalized this appeal by stating that Catholics have an obligation to actively and responsibly take part in the political life of the nation.

The referendum was held on June $7^{\text {th }}$ and $8^{\text {th }}, 2003.58 .85 \%$ of eligible voters took part in it. $77.45 \%$ of participating voters supported Poland's entry into the European Union (Table 5).

Tab. 5 Results of pre-referendum polls and actual EU membership referendum results

\begin{tabular}{|l|c|c|c|}
\hline \multirow{2}{*}{} & \multicolumn{2}{|c|}{ Years } & Results of the \\
\cline { 2 - 3 } & $\mathbf{1 9 9 9}$ & $\mathbf{2 0 0 2}$ & $\mathbf{2 0 0 3}$ referendum \\
\hline For entry & $55 \%$ & $62 \%$ & $77.45 \%$ \\
\hline Against entry & $26 \%$ & $22 \%$ & $22.55 \%$ \\
\hline Undecided & $19 \%$ & $16 \%$ & - \\
\hline
\end{tabular}

Source: compilation of data based on Leszczyńska 2002: 12; Referendum 2003.

\section{Conclusions}

In summary, after nineteen years of the transformation of Polish society, it must be said that the process had not yet ended. A number of signs of Polish society's adoption of certain Western European social characteristics can be observed. The most important of these is the growing number of individuals who declare themselves to be non-religious. Another important process is the decline of the significance of Roman Catholic teachings as guidelines on moral issues. Hence, it 
can be hypothesized that the religious attitudes of Polish society are still in a transition state.

Is Polish society becoming more secular? It is very difficult to answer this question. Previous research has shown that Polish society becomes more religious following important events associated with Pope John Paul II. His death in 2005 was followed by decreased activity among Roman Catholic faithful. Hence, the question is: Will this decline continue in the years to come as well as what direction will changes in religious attitudes and the religious makeup of Poland take?

\section{Acknowledgements}

Author would like to thank Grzegorz Zębik for translating the article into English.

\section{References}

ADAMCZUK, L., ZDANIEWICZ, W. (eds.) (1991): Kościół katolicki w Polsce 1918-1990. Rocznik statystyczny. Warszawa, GUS, Zakład Socjologii Religii SAC.

ADAMCZUK, L., ZDANIEWICZ, W., ZIĘBA, S. (eds.) (2006): Statystyka diecezji Kościoła katolickiego w Polsce 1992-2004. Warszawa, Instytut Statystyki Kościoła Katolickiego SAC.

Bank Danych Regionalnych GUS (2009): available from: http://www.stat.gov.pl/gus/regionalna_plk_ html.htm (accessed 19. 10. 2009).

BOROWIK, I. (1997): Procesy instytucjonalizacji i prywatyzacji religii w powojennej Polsce. Rozprawy habilitacyjne, no. 323. Kraków, Wydawnictwo Uniwersytetu Jagiellońskiego.

JAN PAWEŁ II (1998): Przemówienia do Biskupów Polskich przybyłych z wizytą ad limina - John Paul II, Speeches to Polish Bishops arriving with an ad limina visie. Warsaw, KAI.

JAN PAWEŁ II (1999): Speech in the Parliament of Poland. In: Jan Paweł II, Polska 1999. Przemówienia i homilie. Warsaw, KAI.

JAN PAWEŁ II (2002): Parting speech at the Balice Airport. In: Bóg bogaty w miłosierdzie. Jan Paweł II w ojczyźnie 16-19 sierpnia 2002. Kraków, KAI.

JAN PAWEŁ II (2003): Discorso di Giovanni Paolo il ai Pellegrini Convenuti per la Canonizzazione di: Józef Sebastian Pelczar Urszula Ledóchowska (Lunedì, 19 maggio 2003). Available from: http://www. vatican.va/holy_father/john_paul_ii/speeches/2003/may/documents/hf_jp-ii_spe_20030519_pelczar-ledochowska_pl.html (accessed 02. 05. 2005).

LESZCZYŃSKA, K. (2002): Imprimatur dla Unii? Kościół katolicki w Polsce i w Czechach wobec Europy i procesów zjednoczeniowych. Kraków, Zakład Wydawniczy „Nomos”.

ŁOZIŃSKI, B. (2007): Powołania kapłańskie i zakonne w Polsce, Tygodnik Katolicki Niedziela [on-line], 2007-02-01. Available from: http://www.niedziela.pl/wiad.php?p=200702\&idw=4 (accessed 19. 10. 2009).

MARIAŃSKI, J. (1993): Religia i Kościół w społeczeństwie pluralistycznym. Polska lat dziewięćdziesiątych. Lublin, Redakcja Wydawnictw KUL.

MARIAŃSKI, J. (1998): Kościół katolicki w społeczeństwie obywatelskim. Refleksje socjologiczne. Lublin, Redakcja Wydawnictw KUL.

MARIAŃSKI, J. (2000): Religijność a życie społeczne. In: ZDANIEWICZ, W., ZEMBRZUSKI, T. (eds.): Kościół i religijność Polaków 1945-1999 (407-432). Studia socjologiczno-religijne, 19. Warszawa, Instytut Statystyki Kościoła Katolickiego SAC.

MARIAŃSKI, J. (2004): Religijność społeczeństwa polskiego w perspektywie europejskiej. Próba syntezy socjologicznej. Kraków, Zakład Wydawniczy „Nomos”. 
PIWOWARSKI, W., PODGÓRSKA, T. (1999): Wiara i wierzenia Polaków w kontekście przemian systemowych. In: KAMIŃSKI R., KOZA S.J., SKORUPA L., ŚWIĘC K. (eds.): W służbie wartościom. Księga pamiątkowa poświęcona księdzu biskupowi profesorowi dr. hab. Kazimierzowi Ryczanowi z okazji 60-lecia urodzin (448-456). Kielce, Wyd. Jedność.

Raport. Polska 5 lat po sierpniu (1986): Londyn.

Referendum (2003): Available from: http://referendum.pkw.gov.pl/sww/kraj/indexA.html (accessed 18. 08. 2005).

Rocznik Statystyczny Rzeczypospolitej Polskiej 1991 (1991): Warszawa, GUS.

Rocznik Statystyczny Rzeczypospolitej Polskiej 1996 (1996): Warszawa, GUS.

Rocznik Statystyczny Rzeczypospolitej Polskiej 2001 (2001): Warszawa, GUS.

Rocznik Statystyczny Rzeczypospolitej Polskiej 2006 (2006): Warszawa, GUS.

Rocznik Statystyczny Rzeczypospolitej Polskiej 2008 (2008): Warszawa, GUS.

Statystyka Kościoła katolickiego 2005 (2005): Available from: http://www.iskk.ecclesia.org.pl/ksieza alumni_siostry_bracia_2005.htm (accessed 19.06.2005).

Wiadomości KAI (2001): No. 47/2001, p. 2.

Wiadomości KAI (2002a): No. 13/2002, p. 9.

Wiadomości KAI (2002b): No. 20/2002, p. 2.

Wiadomości KAI (2002c): No. 49/2002, p. 10.

WIŚNIEWSKA, K. (2005): CBOS: Polacy katolikami na własnych zasadach. Available from: http:// wiadomosci.gazeta.pl/wiadomosci/1,53600,2869694.html $\backslash$ (accessed 02. 05. 2005).

WOJTAS, A. (2009): KRDP: Dalszy spadek liczby powołań - poważnym sygnałem dla duszpasterstwa, e-KAI, 2009-01-22. Available from: http://ekai.pl/wydarzenia/raport/x17732/krdp-dalszy-spadek-liczby-powolan-powaznym-sygnalem-dla-duszpasterstwa/ (accessed 19. 10. 2009).

ZDANIEWICZ, W. (ed.) (2001): Religijność Polaków 1991-1998. Warszawa, Instytut Wydawniczy PAX, Instytut Statystyki Kościoła Katolickiego SAC.

ZDANIEWICZ, W., ADAMCZUK, L. (2009): Praktyki niedzielne. Available from: http://www.iskk.ecclesia. org.pl/praktyki-niedzielne.htm (accessed 02. 01.2009).

\section{Résumé}

\section{Sekularizace a sakralizace. Nová polarizace religiózní krajiny v Polsku v kontextu globalizace a evropské integrace}

Pád komunistické vlády v Polsku vedl nejen ke změně v politické, ekonomické a sociální oblasti, ale také ke změně náboženského charakteru státu. Statistické údaje zejména v průběhu posledních pěti let uvádějí poměrně značné změny náboženského charakteru polské společnosti, což se projevuje především v klesajícím počtu účastníků nedělních mší a zvyšujícím se počtu osob užívajících svaté přijímání. Došlo rovněž ke změnám počtu křtů a seminaristů studujících kněžské povolání.

Otevření státní hranice a nové limity pro kontrolu vlády nad římskokatolickou církví i jiných denominací vytvořilo atmosféru vedoucí $\mathrm{k}$ opětovné spolupráci s podobně smýšlejícími komunitami i jednotlivci v zahraničí. Mezinárodní náboženská setkání vedla také k možnosti vykonávat misijní práci v Polsku.

Vstup Polska do Evropské unie (EU) vzbudil vášnivé společenské debaty. Římskokatolická církev se obecně angažovala ve prospěch vstupu do EU, ale někteří významní představitelé toto rozhodnutí zpochybňovali.

Elżbieta Bilska-Wodecka, PhD Institute of Geography and Spatial Management

Jagiellonian University

7 Gronostajowa St 30-387 Cracow Poland

phone +48 (12) 6645286 e-mail: e.bilska@geo.uj.edu.pl 